\title{
Socio-Economic Consequences of Rural Working Women
}

\author{
Kaur Parneet ${ }^{1 *}$ and Kaur Lavjit ${ }^{2}$ \\ ${ }^{1}$ Department of Sociology, Guru Kashi University, Talwandi Sabo, Punjab, India \\ ${ }^{2}$ Department of Economics and Sociology, Punjab Agricultural University, \\ Ludhiana, Punjab, India \\ *Corresponding author
}

\begin{abstract}
A B S T R A C T
\section{Keywords}

Rural working women,Family and Problems

\section{Article Info}

Accepted:

14 May 2020

Available Online:

10 June 2020

In today's time rural women are managers, secretaries, assistants, clerk, peons, teacher, political leader and even guards. While doing these jobs they have to face many problems. This paper explores the problems of rural working women of Fazilka district of Punjab. The total sample size comprised of 90 respondents from all the six villages were selected randomly. Rural working women face lot of problems such as child rearing problems, neglect of family responsibilities, domestic work problems, misbehaves by family members, problems of participation in social activities with family member's etc.Child care facilities and child care leave for working women should be providedby every organization. Support system at family level and at community level could prove too helpful and goes a long way in mitigating the socio-economic and psychological consequences faced by victims.
\end{abstract}

\section{Introduction}

In Modern times, women's life is not limited to livelihood. Today the position of women is better far better than the past because they got all rights which only men were having (Kapur, 1988).Most importantly in the Indian constitution (1950) the Indian woman was given right to equality (Patnik, 2000). Not only in Indian society, but all over the world women have vital positions. There have been a number of variations in the forms of women but the women specialty is still in the place
(Sharma, 2007). Women do same work as men, even far better from them. In our country a shared education system boosts women's empowerment.

The women became aware of their rights through education (Mukhopadhaya, 2009).Women are happily adopting a profession in every field to gain honorable status in the society. In this way they are on the path to growth while enjoying family life (Rao, 1985 and Bathla, 1998). The economic situation of the people is not good. 
In this modern society not only married women do work but un-married also (Singh, 2004).In rural area status of women is changing day by day. In previously rural women are limited to household chores and agricultural pursuits. But in today's time rural women are taking part in every field. They are participating in governmental sectors, through education.

Rural women were aware of their right's and have their own identity (Draze and Sen, 2013 and Kaur, 2012). In the past, rural women were completely dependent on men but now it is not so. The social situation of rural women has undergone many changes. In the past, rural women were limited to small scale and domestic activities such as hand spinning, hand weaving, oil producing, rice pounding, leather work, tailoring etc. These occupations have undergone a number of changes (Anita, 2000). Rural women are today's managers, secretaries, assistants, clear, poems, operators, political leader and even are guards. Where doing these jobs they have to face many problems. Problem means when they perform their duty. Whether those problems are family members or location related issues. In this way women, have to face lot of problems in society (Singh, 1992 and Swarna, 1993).

\section{Materials and Methods}

The present study was conducted to examine the problems of rural working women in Fazilka District of Punjab. Fazilka district was randomly selected to make the study representative of whole South Western Region. Three blocks were randomly selected from Fazilka district and two villages from each block were taken for motive of research.

The total sample size involved of 90 respondents from three blocks of selected district and 15 working women from each village were selected randomly.

\section{Results and Discussion}

\section{Socio-economic consequences}

A Socio-economic outcome refers to situation in which a person's family, social and economic outcomes are discussed. This paper describes every aspect of the lives of rural working women such as social and economic effects.

\section{Reason for working}

A person performs a variety of tasks during the day. Everyone has a reason to work. Many people work because they don't like being free. On the basis of reason, The Data in the Table 1 revealed that one third $(32.22 \%)$ of the respondent worked because of poverty, one fifth $(21.11 \%)$ of the respondent worked because of their hobby, twenty percent $(20.00 \%)$ of the respondent worked to be selfIndependent, twelve percent of the respondent needed money to fulfill their basic necessities. Ten percent of the respondent worked to pass their time, another $(1.11 \%)$ of the respondent worked in compulsion because their parents forced them to work, One percent of respondent worked to increase their knowledge. The Data shows that majority (32.22\%) of respondent worked because of poverty.

\section{Problem faced at the beginning of the work}

A problem is a situation in which a person feels insecure. The problem is not one of kind; there are various types of problem such as social, economic, political, religious etc. Distribution of the respondent on the basis of problems encountered at the beginning of their work shows that in the Table 2 the majority $(83.00 \%)$ of the respondent had no problem at the beginning of their work, three percent of the respondent had political problems, like-there were attempts by 
political parties to quit the job. just three percent of the respondent had problem in understanding the task at work in the beginning such as not understanding the work, another $(3.33 \%)$ of the respondent had faced problem due to shortage of labour in the market, two percent of the respondent had faced problem due to the unsupportive family system in society such as their in laws family did not allow them to work.

There are just one percent of the respondents whose husband did not allowed them to work outside the house. One percent of the respondent had faced problem due to illiteracy. Another one respondent who took loan from various sources from the market to start venture because they are economically week, only one percent of the respondent had hygienic problems for example skin problem, wastage etc. Overall the majority of respondent had no problem at the beginning of work because of their abilities. They had no problems at the beginning of the work.

\section{Work - hours}

Every scheduled time is different for the working hours at the job. On the basis of work hours, the Data in the Table 3 revealed that half $(52.00 \%)$ of the respondent were working for 5-8 hours per day. One fifth $(21.11 \%)$ of the respondents worked for four hours, fourteen percentage of the respondents worked for more than 12 hours per day and only twelve percent of the respondents worked for 9-12 hours at their job place. Overall the majority of respondents were working for 5-8 hours because their work was 5-8 hours.

\section{Children behavior toward respondents}

It is very important to take care of children at work as well as job .Due to workaholic women spends less time with their children.
As a result, children's attitude toward their parents changed day by day. Distribution of the respondents on the basis of children behavior, the Table 4 , revealed that majority $(64.44 \%)$ of the respondents faced abusive behavior of their children towards them such as the children use to abuse them and sometimes beat them.

Seven percent of the respondents reported that their children greatly respected them and obeyed them. Twenty seven percent respondents had no child, overall majority of the respondents felt that their children behavior was abusive with them. It is all because of the work trend in the society.

\section{Trouble in growing up children}

The Distribution of the respondents on the basis of trouble in growing up their children, the Data in the Table 5, reported that fifty eight percent of the respondents had problem in growing up their children such as they cannot pay attention towards their education, due to lack of money they would not fulfill their desires etc. Twenty five percent of the respondents had no child as in the previous Table (1.) reports. In the Table-2, respondents had no problems in growing up their children. Such as they provide good education, they fulfill their needs etc. Majority of respondents had no problem in growing up their children.

\section{Respondents treated by family members}

Distribution of the respondents on the basis of treated by family members. The Data in the Table 6 , revealed that majority $(80.00 \%)$ of the respondents had faced abusive behavior from their family because of the job like family members considered them to be characterless, their income related dispute did not help with household chores. Thirteen percent of the respondents had faced neutral family behavior like family members didn't 
like coming home late, sometimes they asked to leave the job. Only six percent of the respondents get full co-operation from their family members like caring for children, helping to cook. Overall majority of the respondents had reported that their family did not treat them properly. Family members use abusive words from them just because they were earning for their livelihood.

\section{Participation in social activities with family members}

Distribution of the respondents on the basis of participation in social activities with family members, Data in the Table 7 revealed that $(62.22 \%)$ of the respondents never participated in social activities with their family because they had no time to involve in social activities.

One sixth $(15.00 \%)$ of the respondents had rarely participated, respondents revealed that it was difficult to get involved in social activities due to their job, if it is important to go than they had to take leave and get involved in social activities.

Thirteen percent of the respondents were sometimes participated in social activities and only eight percent of the respondents had full involvement in social activities with family like marriage, birthday party, shagun ceremony, bhog ceremony and more. But overall majority of the women never participate in the social activities likemarriage, birthday party etc.

\section{Take care of family responsibilities}

Everyone has different social and family situations. Depending on the situation the individual has certain responsibilities. The distribution of the respondents on the basis of family responsibilities, the data in the Table 8, shows that majority $(66.66 \%)$ of the respondents didn't take care of their family responsibilities well. One third $(33.33 \%)$ of the respondents take care of their family responsibilities well like they did household chores, looked after the children, take care of family etc.

\section{Anybody helps in household work of respondent}

A person performs multiple tasks in his/her life. Famous Sociologist Durkheim gave the theory of division of labor. The concept division of labour has been used in three ways: (a) In the sense of the technical division of labour, it describes the production process. (b) As the sexual division of labour, it describes social divisions between men and women. (c) As the social division of labour, it refers to differentiation in society as whole. (Durkheim, 1956).

Distribution of the respondents on the basis of anybody helps in the household work of respondents. In the Table-9 revealed that sixty one percent of the respondents reported that nobody helped in their household work. Only $(38.88 \%)$ of the respondents told that their family members helped in their household work like cooking, laundry, cleaning etc.

\section{Relative and neighbor's behavior towards respondents}

The Distribution of the respondents on the basis of relative and neighbors behavior towards them. The data in the Table 10 revealed that majority $(76.66 \%)$ of the respondents were reported that their relatives and neighbors behavior was abusive. One sixth $(17.77 \%)$ of the respondents had neutral behavior. Only five percent of the respondents were belonged to co-operative behavior towards relatives and neighbors. Majority of the respondents were reported that their relative and neighbors behavior was abusive. 
Table.1 Distribution of the respondent on the basis of reason for working

\begin{tabular}{|c|c|c|c|c|}
\hline $\begin{array}{c}\text { Reason for } \\
\text { Working }\end{array}$ & $\begin{array}{c}\text { Block-I } \\
\text { Arniwala } \\
(\mathbf{n = 3 0 )}\end{array}$ & $\begin{array}{c}\text { Block-II } \\
\text { Khuiyar Sarwar } \\
(\mathbf{n = 3 0})\end{array}$ & $\begin{array}{c}\text { Block-III } \\
\text { Jalalabad } \\
(\mathbf{n = 3 0})\end{array}$ & $\begin{array}{c}\text { Fazilka } \\
\text { (N=90) }\end{array}$ \\
\hline Poverty & $8(26.66)$ & $8(26.66)$ & $13(43.33)$ & $29(32.22)$ \\
\hline Hobby & $6(20.00)$ & $7(23.33$ & $6(20.00)$ & $19(21.11)$ \\
\hline Self- Independent & $7(23.33$ & $6(20.00)$ & $5(16.66)$ & $18(20.00)$ \\
\hline Need money & $7(23.33)$ & $2(6.66)$ & $2(6.66)$ & $11(12.22)$ \\
\hline Time pass & $1(3.33)$ & $5(16.66)$ & $3(10.00)$ & $9(10.00)$ \\
\hline $\begin{array}{c}\text { Agricultural+ } \\
\text { Business }\end{array}$ & $1(3.33)$ & - & - & $1(1.11)$ \\
\hline Compulsion & - & - & - & $1(1.11)$ \\
\hline Unemployment & - & $1(3.33)$ & - & $1(1.11)$ \\
\hline Increase knowledge & - & - & $1(3.33)$ & $1(1.11)$ \\
\hline
\end{tabular}

Note- Figure in the parenthesis indicates percentage

Table.2 Distribution of the respondent on the basis of what kind of problem they faced at the beginning of work

\begin{tabular}{|c|c|c|c|c|}
\hline $\begin{array}{c}\text { Kind of Problem } \\
\text { When starting work }\end{array}$ & $\begin{array}{c}\text { Block-I } \\
\text { Arniwala } \\
(\mathbf{n = 3 0})\end{array}$ & $\begin{array}{c}\text { Block-II } \\
\text { Khuiyar Sarwar } \\
(\mathbf{n = 3 0})\end{array}$ & $\begin{array}{c}\text { Block-III } \\
\text { Jalalabad } \\
(\mathbf{n = 3 0})\end{array}$ & $\begin{array}{c}\text { Fazilka } \\
\text { (N=90) }\end{array}$ \\
\hline $\begin{array}{c}\text { No problem } \\
24(80.00)\end{array}$ & $24(80.00)$ & $27(90.00)$ & $75(83.33)$ \\
\hline Un-supportive family & $1(3.33)$ & $1(3.33)$ & - & $2(2.22)$ \\
\hline $\begin{array}{c}\text { Un-supportive } \\
\text { husband }\end{array}$ & $1(3.33)$ & - & - & $1(1.11)$ \\
\hline $\begin{array}{c}\text { Due to illiterate } \\
\text { Get a loan start work }\end{array}$ & $1(3.33)$ & - & - & $1(1.11)$ \\
\hline Political issue & - & $1(3.33)$ & - & $1(1.11)$ \\
\hline $\begin{array}{c}\text { Problems in start up } \\
\text { of work }\end{array}$ & - & $1(3.33)$ & $1(3.33)$ & $3(3.33)$ \\
\hline Due to lack of labour & $2(6.66)$ & $2(6.66)$ & $1(3.33)$ & $3(3.33)$ \\
\hline Hygienic Problem & - & $1(3.33)$ & - & $3(3.33)$ \\
\hline
\end{tabular}

Note: - Figure in the parenthesis indicates percentage

Table.3 Distribution of the respondents on the basis of working hours

\begin{tabular}{|c|c|c|c|c|}
\hline Working hours & $\begin{array}{c}\text { Block-I } \\
\text { Arniwala } \\
(\mathbf{n = 3 0})\end{array}$ & $\begin{array}{c}\text { Block -II } \\
\text { Khuiyar Sarwar } \\
(\mathbf{n = 3 0})\end{array}$ & $\begin{array}{c}\text { Block-III } \\
\text { Jalalabad } \\
(\mathbf{n = 3 0})\end{array}$ & $\begin{array}{c}\text { Fazilka } \\
\mathbf{( N = 9 0 )}\end{array}$ \\
\hline $\mathbf{0 - 4}$ hours & $4(13.33)$ & $7(23.33)$ & $8(26.66)$ & $19(21.11)$ \\
\hline $\mathbf{5 - 8}$ hours & $24(80.00)$ & $12(40.00)$ & $11(36.66)$ & $47(52.22)$ \\
\hline 9-12 hours & $2(6.66)$ & $4(13.33)$ & $5(16.66)$ & $11(12.22)$ \\
\hline Above 12 hours & 0 & $7(23.33)$ & $6(20.00)$ & $13(14.44)$ \\
\hline
\end{tabular}

Note- figure in the parenthesis indicate percentage 
Table.4 Distribution of the respondents on the basis of children behavior towards respondents

\begin{tabular}{|c|c|c|c|c|}
\hline $\begin{array}{c}\text { Children } \\
\text { behavior }\end{array}$ & $\begin{array}{c}\text { Block }- \text { I } \\
\text { Arniwala } \\
(\mathbf{n = 3 0})\end{array}$ & $\begin{array}{c}\text { Block -II } \\
\text { KhuiyanSarwar } \\
(\mathbf{n = 3 0 )}\end{array}$ & $\begin{array}{c}\text { Block-III } \\
\text { Jalalabad } \\
(\mathbf{n = 3 0})\end{array}$ & $\begin{array}{c}\text { Fazilka } \\
(\mathbf{N}=\mathbf{9 0})\end{array}$ \\
\hline Normal & $3(10.00)$ & $3(10.00)$ & $1(3.33)$ & $7(7.77)$ \\
\hline Abusive & $17(56.66)$ & $19(63.33)$ & $22(73.33)$ & $58(64.44)$ \\
\hline No child & $10(33.3)$ & $8(26.66)$ & $7(23.33)$ & $25(27.77)$ \\
\hline
\end{tabular}

Note- Figure in the parentheses indicate percentage

Table.5 Distribution of the respondent on the basis of trouble in growing up children

\begin{tabular}{|c|c|c|c|c|}
\hline $\begin{array}{c}\text { Trouble in } \\
\text { growing up } \\
\text { children }\end{array}$ & $\begin{array}{c}\text { Block -I } \\
\text { Arniwala } \\
(\mathbf{n = 2 0})\end{array}$ & $\begin{array}{c}\text { Block -II } \\
\text { KhuiyanSarwar } \\
(\mathbf{n = 3 0})\end{array}$ & $\begin{array}{c}\text { Block-III } \\
\text { Jalalabad } \\
(\mathbf{n = 2 3})\end{array}$ & $\begin{array}{c}\text { Fazilka } \\
(\mathbf{N}=\mathbf{6 5})\end{array}$ \\
\hline Yes & $12(40.00)$ & $19(63.33)$ & $22(73.33)$ & $53(58.88)$ \\
\hline No & $8(26.66)$ & $3(10.00)$ & $1(3.33)$ & $12(13.33)$ \\
\hline
\end{tabular}

Note- Figure in the parentheses indicate percentage

Table.6 Distribution of the respondents on the basis of treated by family members

\begin{tabular}{|c|c|c|c|c|}
\hline Family Treat & $\begin{array}{c}\text { Block }-\mathbf{I} \\
\text { Arniwala } \\
(\mathbf{n = 3 0})\end{array}$ & $\begin{array}{c}\text { Block-II } \\
\text { Khuiyan Sarwar } \\
(\mathbf{n = 3 0})\end{array}$ & $\begin{array}{c}\text { Block-III } \\
\text { Jalalabad } \\
(\mathbf{n = 3 0})\end{array}$ & $\begin{array}{c}\text { Fazilka } \\
(\mathbf{N = 9 0})\end{array}$ \\
\hline Co-operative & $3(10.00)$ & $2(6.66)$ & $1(3.33)$ & $6(6.66)$ \\
\hline Neutral & $3(10.00)$ & $6(20.00)$ & $3(10.00)$ & $12(13.33)$ \\
\hline Abusive & $24(80.00)$ & $22(73.33)$ & $26(86.66)$ & $72(80.00)$ \\
\hline
\end{tabular}

Note- Figure in the parentheses indicate percentage

Table.7 Distribution of the respondents on the basis of participation in social activities with family members

\begin{tabular}{|c|c|c|c|c|}
\hline $\begin{array}{c}\text { Participation in } \\
\text { social activities }\end{array}$ & $\begin{array}{c}\text { Block }- \text { I } \\
\text { Arniwala } \\
(\mathbf{n = 3 0})\end{array}$ & $\begin{array}{c}\text { Block -II } \\
\text { Khuiyan Sarwar } \\
(\mathbf{n = 3 0})\end{array}$ & $\begin{array}{c}\text { Block-III } \\
\text { Jalalabad } \\
(\mathbf{n = 3 0})\end{array}$ & $\begin{array}{c}\text { Fazilka } \\
(\mathbf{N = 9 0})\end{array}$ \\
\hline Always & $2(6.66)$ & $4(13.33)$ & $2(6.66)$ & $8(8.88)$ \\
\hline Never & $16(53.33)$ & $21(70.00)$ & $19(63.33)$ & $56(62.22)$ \\
\hline Rarely & $9(30.00)$ & $1(3.33)$ & $4(13.33)$ & $14(15.55)$ \\
\hline Sometime & $3(10.00)$ & $4(13.33)$ & $5(16.66)$ & $12(13.33)$ \\
\hline
\end{tabular}

Note-Figure in the parentheses indicate percentage

Table.8 Distribution of the respondents on the basis of take care of family responsibilities well or not

\begin{tabular}{|c|c|c|c|c|}
\hline $\begin{array}{c}\text { Take care of family } \\
\text { responsibilities well or } \\
\text { not }\end{array}$ & $\begin{array}{c}\text { Block -I } \\
\text { Arniwala } \\
(\mathbf{n = 3 0 )}\end{array}$ & $\begin{array}{c}\text { Block -II } \\
\text { KhuiyanSarwar } \\
(\mathbf{n = 3 0 )}\end{array}$ & $\begin{array}{c}\text { Block-III } \\
\text { Jalalabad } \\
(\mathbf{n = 3 0})\end{array}$ & $\begin{array}{c}\text { Fazilka } \\
(\mathbf{N = 9 0 )}\end{array}$ \\
\hline Yes & $10(33.33)$ & $12(40.00)$ & $8(26.66)$ & $30(33.33)$ \\
\hline No & $20(66.66)$ & $18(60.00)$ & $22(73.33)$ & $60(66.66)$ \\
\hline
\end{tabular}

Note-Figure in the parentheses indicate percentage 
Table.9 Distribution of the respondents on the basis of anybody helps in household work of respondent

\begin{tabular}{|c|c|c|c|c|}
\hline Help & $\begin{array}{c}\text { Block-I } \\
\text { Arniwala } \\
(\mathbf{n = 3 0}\end{array}$ & $\begin{array}{c}\text { Block -II } \\
\text { Khuiyan Sarwar } \\
(\mathbf{n = 3 0}\end{array}$ & $\begin{array}{c}\text { Block-III } \\
\text { Jalalabad } \\
(\mathbf{n = 3 0})\end{array}$ & $\begin{array}{c}\text { Fazilka } \\
\text { (N=90) }\end{array}$ \\
\hline Yes & $8(26.66)$ & $12(40.00)$ & $15(50.00)$ & $35(38.88)$ \\
\hline No & $22(73.33)$ & $18(60.00)$ & $15(50.00)$ & $55(61.11)$ \\
\hline
\end{tabular}

Note- Figure in the parentheses indicate percentage

Table.10 Distribution of the respondents on the basis of relative and neighbors behavior towards them

\begin{tabular}{|c|c|c|c|c|}
\hline $\begin{array}{c}\text { Relative and } \\
\text { neighbors } \\
\text { behavior }\end{array}$ & $\begin{array}{c}\text { Block -I } \\
\text { Arniwala } \\
(\mathbf{n = 3 0})\end{array}$ & $\begin{array}{c}\text { Block -II } \\
\text { Khuiyan Sarwar } \\
(\mathbf{n = 3 0})\end{array}$ & $\begin{array}{c}\text { Block-III } \\
\text { Jalalabad } \\
(\mathbf{n = 3 0})\end{array}$ & $\begin{array}{c}\text { Fazilka } \\
(\mathbf{N}=90)\end{array}$ \\
\hline Co-operative & $3(10.00)$ & $1(3.33)$ & $1(3.33)$ & $5(5.55)$ \\
\hline Neutral & $5(16.66)$ & $7(23.33)$ & $4(13.33)$ & $16(17.77)$ \\
\hline Abusive & $22(73.33)$ & $22(73.33)$ & $25(83.33)$ & $69((76.66)$ \\
\hline
\end{tabular}

Note- Figure in the parentheses indicate percentage

Table.11 Distribution of the respondents on the basis of control of family finance

\begin{tabular}{|c|c|c|c|c|}
\hline $\begin{array}{c}\text { Control of } \\
\text { family } \\
\text { finance }\end{array}$ & $\begin{array}{c}\text { Block-I } \\
\text { Arniwala } \\
(\mathbf{n = 3 0})\end{array}$ & $\begin{array}{c}\text { Block-II } \\
\text { KhuiyanSarwar } \\
(\mathbf{n = 3 0})\end{array}$ & $\begin{array}{c}\text { Block-III } \\
\text { Jalalabad } \\
(\mathbf{n = 3 0})\end{array}$ & $\begin{array}{c}\text { Fazilka } \\
(\mathbf{N = 9 0})\end{array}$ \\
\hline Father & $13(43.33)$ & $14(46.66)$ & $14(46.66)$ & $41(45.05)$ \\
\hline Mother & $1(3.33)$ & - & - & $1(1.11)$ \\
\hline Husband & $10(33.33)$ & $9(30.00)$ & $12(40.00)$ & $31(34.44)$ \\
\hline Respondent & $6(20.00)$ & $7(23.33)$ & $4(13.33)$ & $17(18.88)$ \\
\hline
\end{tabular}

Note-Figure in the parentheses indicate percentage

Table.12 Distribution of the respondents on the basis of good economic situation improves respect in society

\begin{tabular}{|c|c|c|c|c|}
\hline $\begin{array}{c}\text { Economic situation } \\
\text { increase respect in } \\
\text { society }\end{array}$ & $\begin{array}{c}\text { Block -I } \\
\text { Arniwala } \\
(\mathbf{n = 3 0})\end{array}$ & $\begin{array}{c}\text { Block -II } \\
\text { Khuiyan Sarwar } \\
(\mathbf{n = 3 0})\end{array}$ & $\begin{array}{c}\text { Block-III } \\
\text { Jalalabad } \\
(\mathbf{n = 3 0})\end{array}$ & $\begin{array}{c}\text { Fazilka } \\
(\mathbf{N = 9 0})\end{array}$ \\
\hline Yes & $7(23.33)$ & $8(26.66)$ & $9(30.00)$ & $24(26.66)$ \\
\hline No & $23(76.66)$ & $22(73.33)$ & $21(70.00)$ & $66(73.33)$ \\
\hline
\end{tabular}

Note- Figure in the parentheses indicate percentage 


\section{Economic consequences}

\section{Family finance}

The Distribution of the respondents on the basis of control of family finance In the Table 11 revealed that nearly half $(45.55 \%)$ of the respondents reported that their father had control on their family expenditure because their family head was their father. One third $(34.44 \%)$ of the respondents reported that their husband control's their family expenditure, eighteen percent of the respondents had control on their family expenditure because they did not want to share their pay with anyone. Only $(1.11 \%)$ of the respondents reported that their mother control their family expenditure. Overall majority of respondent's father had control their family finance.

A person who has good economic status also has a high social status. Rich person get more respect in society (Aadya and Kiran, 2013). The distribution of the respondents on the basis of good economic situation increase respect in society, In the Table 12 shows that majority $(73.00 \%)$ of the respondents that having a good economic status does not bring much respect in society to them. Only one fourth $(26.77 \%)$ of the respondents reported that having a good economic status bring much respect in society to them. Most of the respondents felt that a good economic status would not bring more respect in society to them.

The problems of rural working women were manifold and multifaceted. Working women had dual responsibility to balance their family and job. The data revealed that majority of the respondents felt that their children behavior was abusive with them. Women had problem in growing up their children. Working women reported that their family did not treat them properly.
Respondents never participated in social activities with their family because they had no time to involve in social activities. Eighteen percent of the respondents had control on their family expenditure because they did not want to share their pay with anyone. During the research it was observed that working women had to face many other problems. Families of working women should treat them with respect and help with household chores. Support system at family level could prove too helpful and goes long way in mitigating the socio- economic consequences faced by victims.

\section{References}

Anita, A. (2000). Indian Women Work and Development. Vol. 3.Ghyan Publishing House. New Delhi.

Bathla, S. (1998). Women Democracy and the Media .Sage Publication. New Delhi.

Dreze, J. and Sen, A. (2013). An Uncertain Story: India and Contradictions. Princeton University Press.USA.

Durkheim, E. (1956). Education and Sociology. The Free Press Toronto.

Kapur, P. (1988). The Changing Status of Working Women in India. Vikas Publishing House .New Delhi.

Kaur, S. (2012). A Study of Adjustment of High School Students in Relation to their Achievement, Sex and Locality. International $J$ of Research in Education.1 (2).pp. 18-21.

Mukhopadhyaya, D. (2009). Education and Empowerment of Women.Women Education and Develpoment. 8 (4).pp. 83-204.

Patnik, B.K. (2000). Women Welfare and Social Development. $J$ of Applied and Pure Science and Agriculture. 44 (9). Pp. 24-25.

Rao, R.R. (1985). Shift in Female Work Participation. $J$ of Social Welfare. 31 (34). Pp. 33-39. 
Sharma, K.L. (2007). Indian Social Structure and Social Change.Rawat Publications. New Delhi.

Singh, B. (2004). Working Women in India.Anmol Publications. New Delhi.

Singh, B.K. (1992). Age of Marriage: The
Changing Trends in India. Indian $J$ of Social Research. 33 (35). pp. 89-95.

Swarna, E.V. (1993). Women Education and Occupational Aspirations. Discovery Publishing House. New Delhi.

\section{How to cite this article:}

Kaur Parneet and Kaur Lavjit. 2020. Socio-Economic Consequences of Rural Working Women. Int.J.Curr.Microbiol.App.Sci. 9(06): 161-169.

doi: https://doi.org/10.20546/ijcmas.2020.906.021 